\title{
The Effect of Advertising and In-Store Promotions on the Demand for Chocolate
}

\author{
Jason C. Patalinghug ${ }^{1}$ \\ ${ }^{1}$ Department of Economics, University of New Haven, West Haven, CT, USA \\ Correspondence: Jason C. Patalinghug, Department of Economics, University of New Haven, 300 Boston Post \\ Rd. West Haven, CT, 06516, USA. Tel: 1-203-932-1137. E-mail: jpatalinghug@ newhaven.edu
}

Received: July 19, 2015

Accepted: August 28, 2015

Online Published: September 25, 2015

doi:10.5539/ijef.v7n10p56

URL: http://dx.doi.org/10.5539/ijef.v7n10p56

\begin{abstract}
This paper analyzes the effect of TV advertising and in-store displays on the sales of chocolates. I examine which method is more effective in gaining customers and in increasing total sales. Also, I look at the evidence to see whether the lack of advertising by a firm will hurt the industry as a whole. In this paper, I use a nested logit model on scanner data obtained by the Zwick Center for Food and Resource Policy at the University of Connecticut to examine the effect of TV advertising on chocolate sales. The results show that in-store displays and advertising both help increase the demand for chocolate.
\end{abstract}

Keywords: nested logit, scanner data, advertising, in-store promotions

\section{Introduction}

The candy industry is the third largest consumer food industry in terms of total sales in the United States behind soft drinks and milk. Advertising plays an important role in the marketing strategies of companies. General Motors spent $\$ 3.65$ billion in 2002 to advertise automobiles and trucks, and Procter and Gamble spent \$3.32 billion in 2003 to advertise detergents and cosmetics (Carlton \& Perloff, 2005; Bagwell, 2005). Among chocolate companies, Hershey spent \$414 million in 2011 and Mars $\$ 630$ million in 2011 to advertise their products. The success of firms can sometimes depend on the marketing strategy that they implement. Scott and Walker (2010) illustrate that promotional activities proved key to the success of British department stores in fending off competition from chain stores during the interwar years. I estimate the demand for chocolate using the product space characteristic approach. This essay utilizes a nested logit model to look into the role that advertising and in-store displays play in the demand for chocolate. This paper looks into the effectiveness of in-store displays and television ads on the demand for chocolate. I use scanner and advertising data that cover 16 metropolitan areas in the U.S. over a three-year period. I try out two specifications of my model: one where Hershey and Mars form the two nests and one where chocolate brands with nuts and without nuts form the two nests. I also calculate the elasticities for each brand.

Before I review the literature on advertising and the chocolate industry I provide some background data on the chocolate industry. Table 1 shows the market value of the chocolate industry as well as the volume consumed of chocolate from 2007 to 2011 . The compound annual growth rate (CAGR) of market value over those years is $2 \%$ which is less than that of the European (2.8\%) and Asian (3.6\%) markets (MarketLine, 2013). Consumption value had a CAGR of $0.9 \%$ between 2007 and 2011.

Table 1. US chocolate industry market value and market volume 2007-2011

\begin{tabular}{rrrrr}
\hline Year & Market Value (\$ million) & \% Growth & Market Volume (million kg.) & \% Growth \\
\hline 2007 & 16321.2 & & 1599.5 & \\
2008 & 16668.1 & 2.1 & 1620.7 & 1.3 \\
2009 & 16994.2 & 2.0 & 1635.2 & 0.9 \\
2010 & 17327.7 & 2.0 & 1648.0 & 0.8 \\
2011 & 17664.1 & 1.9 & 1660.0 & 0.7 \\
\hline
\end{tabular}

Source. MarketLine (2013). 
Figure 1 shows the market shares of the major players in the chocolate market. We see that Hershey and Mars combine for more than $70 \%$ of the market's value with Hershey being the top chocolate maker in the country with a $40.6 \%$ share. If we add the other big players (Nestle and Russell Stover) the big four chocolate firms would control about $86 \%$ of the market thus it is a very concentrated industry.

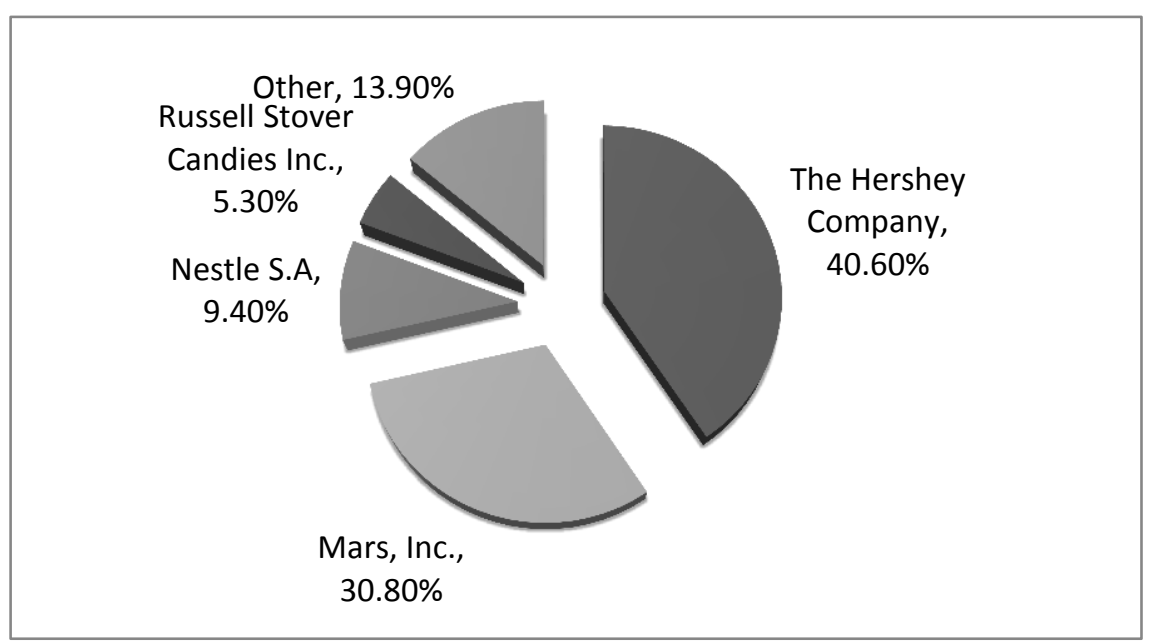

Figure 1. U.S. chocolate industry market share (\% Share, by Value 2011)

Source. MarketLine (2013).

Figure 2 shows the distribution channel of the chocolate market. Supermarkets/hypermarkets and independent retailers combined account for about $57 \%$ of the market's value. Table 2 shows the demographics of chocolate consumers in the U.S. We see that majority of chocolate consumers are white or married or employed. Almost half have children under the age of 18 and most reside in either the South or the Midwest.

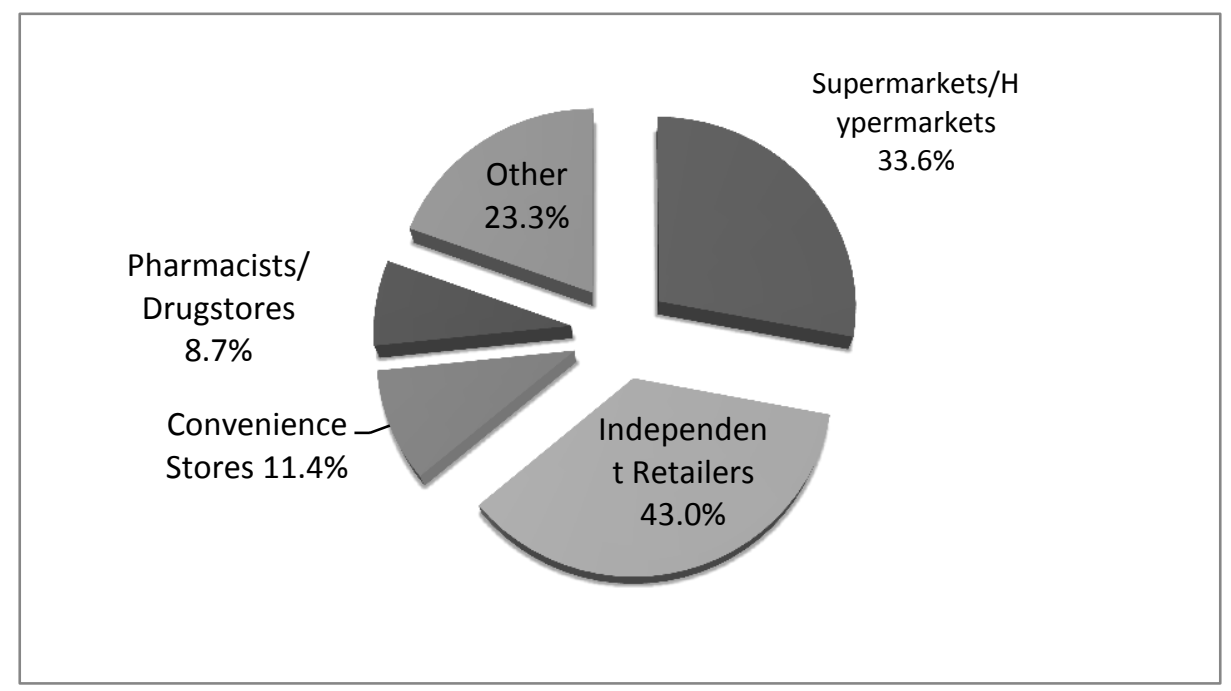

Figure 2. U.S. chocolate market distribution (\% Share, by Value, 2011)

Source. MarketLine (2013). 
Table 2. Chocolate consumer demographics

\begin{tabular}{ll}
\hline Demographic & \\
\hline Location & $40 \%$ South, 24\% Midwest, 22\% West, 18\% Northeast \\
Race & $70 \%$ Non-Hispanic White \\
Marital Status & $53 \%$ Married \\
Family Status & $43 \%$ Have Children Under 18 \\
Employment Status & $53 \%$ Employed \\
Education & $28 \%$ College Degree or More \\
Income & $24 \%$ Household Income $>\$ 100000$ \\
\hline
\end{tabular}

Source. National Confectioners Association (n.d.).

The next section discusses the literature relevant to this study. I then explain my model, data, and estimation strategy, followed by a discussion of the estimation results and elasticities and the conclusion.

\section{Review of Related Literature}

The history of promoting chocolate is almost as old as the industry itself. Rossfeld (2008) examined the history of the Swiss chocolate company Suchard and the Verband Reisender Kaufleute der Schweiz (Association of Swiss Commercial Travelers) and described the economic significance, social image, and everyday life of traveling salesmen between 1860 and 1920. By 1900, commercial travelers formed a critical link between the enterprise and the market, helping to drive the vertical integration of production and distribution. Many of them were promoted to executive levels and they were largely responsible for obtaining information and expanding product sales in an era that preceded specialized market research and the domination of advertising companies.

Fitzgerald (2005) examined the development of marketing in Cadbury from 1900 to 1939. He stated that by 1939, Cadbury's marketing knowhow was a main factor in its commercial expansion and it exerted its influence on the nature of the confectionery industry.

There has been significant debate in the literature about the effect of advertising on sales. Eagle and Ambler (2002) found no association between the weight of advertising and market growth in the chocolate industry among five Western European countries (Belgium, France, Germany, the Netherlands and the United Kingdom). They also found that the Western European market is mature and shows signs of slow growth.

Allenby and Ginter (1995) examined the influence of merchandising variables on household consideration sets using a scanner-panel dataset of tuna purchases. They showed that consideration sets do exist and that in-store displays and feature advertisements influence inter-brand competition through these household consideration sets. Households more actively consider the price of brands within their consideration set compared to brands outside of it.

Woodside and Waddle (1975) found that consumers bought more goods when there is a point-of-sale promotion compared to a price reduction. Bemmaor and Mouchoux (1991) found a strong positive interaction between price reduction and advertising is evidenced, and that this interaction effect is smaller for the leading brands.

Kumar and Leone (1988) used store-level scanner data to investigate the effect of retail store price promotion, featuring, and displays on sales of brands of disposable diapers within a city. They found that within a store, price promotion produced the largest amount of substitution followed by featuring and displays. These activities also produced store substitution in some cases.

Volle (2001) examined the short-term effects of store level promotions (weekly flyers, radio and outdoor advertising) on grocery store choices. He estimated household-level multinomial logit models of store choice on panel data. His results showed that the short-term effect of store-level promotions on store choice was weak and that store choice is mostly driven by loyalty.

Allenby and Lenk (1995) used a random-effects, autocorrelated, logistic regression model to anlayze brand choice decisions. Their estimates on the influence on in-store displays and feature advertisement on switching is shown to be about two to three times more effective than estimates of previous studies.

Walters and MacKenzie (1988) developed a series of hypotheses about the effects of loss leaders, in-store price specials, and double coupon promotions on overall sales, profit and traffic. They found out that most loss leader promotions had no impact on store profit. They also discovered that double coupon promotions affected profit by increasing sales of products purchased with a coupon rather than by increasing store traffic. Finally, they found that in-store price specials have no effect on store profit, sales or traffic. 
Blattberg et al. (1995) synthesized findings across the sales promotion literature in order to gain a better understanding of how promotions work. They emphasized the need of a standard measure to compare results and also the importance of generalizations.

Shaffer and Zettelmeyer (2009) have stated that the manufacturer will want and the retailer will allow an in-store advertisement of the manufacturer, whether or not compliance can be monitored, if and only if the display would increase the overall joint profit between the retailer and the manufacturer. In their model, if the retailer accepts offers from manufacturer $\mathrm{X}$ and manufacturer $\mathrm{Y}$ to use in-store displays in its store then its payoff will be $\widetilde{\Pi}_{x y}-\pi_{x}-\partial_{y}$ where $\widetilde{\Pi}_{x y}$ represents overall joint profit, $\pi_{x}$ represents manufacturer X's profit and $\pi_{y}$ represents manufacturer Y's profit. If the retailer accepts Y's offer but not X's then its payoff will be $\Pi_{y}-\pi_{y}$. Thus based on the two earlier equations, manufacturer X's payoff must be equal to $\widetilde{\Pi}_{x y}-\Pi_{y}$ if the retailer is to accept X's offer. They also point out that it is optimal for the retailer and the manufacturer to display the manufacturer's ads in store if $s_{x} \geq 1-e\left(x^{*}\right)$ where $\mathrm{s}_{\mathrm{x}}$ is the market share of manufacturer $\mathrm{X}$ and $\mathrm{e}\left(\mathrm{x}^{*}\right)$ is defined as the emphasis of a given advertising message. This means that the probability of the retailer showing an in-store ad is higher if the manufacturer's market share is bigger. Porter (1974) suggests that consumers are more responsive to advertising by manufacturers of convenience goods than non-convenience goods. Convenience goods are low-priced, frequently purchased consumer goods such as soft drinks and toothpaste. Non-convenience goods are high-priced, infrequently purchased consumer goods such as furniture and television (Porter, 1974). Manufacturers of convenience goods have a better bargaining position with retailers.

Cotterill and Haller (1997) found that own advertising and couponing increase sales for the firm while competitor activities reduce sales. Bagwell (2005) distinguished the empirical studies done under the structure-conduct-performance (SCP) approach from those the used the New Empirical Industrial Organization (NEIO) approach. He stated that the SCP approach assumes that there is a stable causal relationship across industries that flows from structure to conduct to performance and that market power can be estimated from available data. The NEIO approach meanwhile does not assume symmetry across industries, does not assume that market power is observable, and it does not treat firm and industry conduct as implications of market structure variables. Bagwell (2005) states the three main ingredients of the NEIO approach: (1) specified demand functions, (2) specified marginal cost functions, and (3) specified supply relationships. One criticism of the SCP approach is that it used inter industry data to measure the effect of structure on performance (e.g. effect of concentration and advertising on profits), but they never addressed that advertising could be endogenous. Inter industry studies may hide the varying effect of advertising on sales by industry. For example, the effect of advertising on sales in furniture industry may be insignificant, but the effect of advertising on sales in cigarette industry might be significantly positive and thus the overall positive effect of advertising on sales in inter industry studies does not reveal the varying effect of advertising by industry.

Ackerberg (2001) used a binary logit model to examine the purchase decisions of households when a new yogurt brand, Yoplait 150, was introduced. He found out that while advertising has a positive and significant effect for inexperienced consumers, it had a small and insignificant effect on experienced ones. Erdem and Keane (1996) used scanner and advertising data for laundry detergent and found that experience gives consumers, who are risk averse, more information than advertising. Because consumers are risk averse, they stay loyal to brands which have given them a positive experience.

Bagwell (2005) stated that there are three main views on advertising: persuasive, informative and complementary. The persuasive view emphasizes the fact that advertising creates brand loyalty and serves as a deterrent for new entrants in an industry. Shum's (2004) study of the cereal industry showed that advertising encourages brand switching by households. Cereal advertising is able to overcome the brand loyalty of consumers by persuading them to try out brands they have never tried before. The informative view stresses the fact that advertising can convey new information to consumers. Finally, the complementary view emphasizes that consumers have stable preferences and advertising serves as a tool to reinforce those preferences.

Bagwell (2005) also reviewed several studies on the effects of advertising on sales and found three main conclusions. First, he found that advertising results in a short-lived increase in sales for the firm. Second, advertising is combative. When a firm increases its advertising it may reduce the sales of its competitors and the competitors strike back with their own increase in advertising. Third, the studies have shown that the effect of 
advertising on demand varies across industries.

\section{Model}

I adopt a nested logit model to estimate the effects of traditional (i.e. television) and in-store advertising on chocolate sales. I assume in this model that consumers choose Hershey, Mars or an outside good and then choose a brand of chocolate within that particular company. I let $G$ denote the set of product groups where $g \in G$. From Berry (1994) the utility of consumer $i$ from choosing a unit of product $j \in g$ is:

$$
u_{i j}=x_{j} \beta-\alpha p_{j}+\xi_{j}+\zeta_{i g}+(1-\sigma) \epsilon_{i j}
$$

where $\mathrm{p}_{\mathrm{j}}$ is the price of product $j, \mathrm{x}_{\mathrm{j}}$ is a vector of observable product characteristics, $\xi_{j}$ is the unobservable utility shocks, $\alpha$ and $\beta$ are parameters and $\zeta_{i g}$ is a common feature of all products in group $g$. The parameter $\sigma$ is between zero and one and it represents the within group correlation of utility levels which also represents a measure of the value of the degree of substitution within the group. Berry (1994) explains that as $\sigma$ approaches one, the within group correlation of utility levels will go to one and as $\sigma$ approaches zero then the within group correlation will go to zero. If $\sigma=1$, the products within the group are perfect substitutes. If $\sigma=0$ then the elasticities of the simple logit and the nested logit would be the same. In a nested logit model the elasticities of demand are weighted by $\sigma . \epsilon_{i j}$ is an identically and independently distributed extreme value.

The market share of brand $j$ within group $g$ is shown as:

$$
S_{j / g}=\frac{\exp \left(\frac{\delta_{j}}{1-\sigma}\right)}{\sum_{j \in g} \exp \left(\frac{\delta_{j}}{1-\sigma}\right)}
$$

where $\delta_{j}=x_{j} \beta+\xi_{j}-\alpha p_{j}$ is the mean utility. The market share of choosing a product within group $g$ is:

$$
S_{g}=\frac{\left(\sum_{j \in g} \exp \left\{\frac{\delta_{j}}{1-\sigma}\right\}\right)^{1-\sigma}}{\sum_{g \in G\left(\sum_{j \in g} \exp \left\{\frac{\delta_{j}}{1-\sigma}\right\}\right)^{1-\sigma}}}
$$

Therefore the market share of brand $j$ can be represented as $s_{j}=s_{j / g} s_{g}$.

When we normalize to zero the mean utility of the outside good (Berry, 1994), the nested logit then becomes:

$$
\ln \left(s_{j}\right)-\ln \left(s_{o}\right)=x_{j} \beta-\alpha p_{j}+\sigma \ln \left(s_{j / g}\right)+\xi_{j}
$$

where $s_{j}$ is the market share of product $j$ for the whole market, $s_{o}$ is the outside good market share and $s_{j / g}$ is the conditional market share of product $j$ in group $g$.

The own price elasticity of brand $j$ is:

$$
\eta_{j j}=\frac{\alpha}{1-\sigma} p_{j}\left(1-\sigma s_{j / g}-(1-\sigma) s_{j}\right)
$$

The cross-price elasticity of brand $j$ is

$$
\eta_{j k}=-\alpha s_{k} p_{k}
$$

if brands $j$ and $k$ belong to the same nest. This shows that the cross-price elasticity of two brands in the same group depends on price sensitivity, market share and the price of the good. The cross price elasticity of brands $j$ and $k$ if they do not belong to the same nest is:

\section{Data and Estimation}

$$
\eta_{j k}=\frac{\alpha}{1-\sigma} p_{k}\left(-\sigma s_{j g}-(1-\sigma) s_{j}\right)
$$

\subsection{Data}

The data from this study comes from two datasets from A.C. Nielsen. It is weekly HomeScan data for the period of February 2006 to December 2008, for sixteen Designated Market Areas (DMAs). I also use A.C. Nielsen television advertising data. These datasets were purchased by the Zwick Center for Food and Resource Policy (formerly the Food Marketing Policy Center) at the Department of Agricultural and Resource Economics at the University of Connecticut. A DMA is a region (usually a group of counties) where the population can receive the same television broadcast. The dataset contains a panel which tracks the chocolate purchases of thousands of 
households. These purchases were made in places such as grocery stores, drug stores, vending machines, and on-line shopping sites. The dataset classifies the data by category, company, subsidiary and brand. Each purchase by a household contains product characteristics (brand Universal Pricing Code, flavor, package and size); marketing information (unit price, price paid, coupon use, in-store display use and features); as well as the location and time of each transaction. The data also contains demographic information such as the age, race and gender of the shoppers, number of children in each household and income. The 16 DMAs are: Atlanta, Baltimore, Boston, Chicago, Detroit, Hartford-New Haven, Houston, Kansas City, Los Angeles, Miami-Ft. Lauderdale, New York, Philadelphia, San Francisco-Oakland-San Jose, Seattle-Tacoma, Springfield-Holyoke, and Washington, D.C.

The advertising data consists of weekly Gross Ratings Points (GRP) at the brand level for each DMA. There are GRPs on both the national (cable, network, and syndicated) and local (spot) level. The dataset also includes advertising expenditures at each level. The market size for each DMA was defined as the per capita consumption of chocolate per month (in ounces) multiplied by the population of the DMA. DMA population data also was provided by A.C. Nielsen. Market shares for each brand were obtained by dividing total sales in ounces per month per DMA by the market size. The data is aggregated to the monthly level resulting in 7,236 observations denoting 13 brands over 35 months and 16 DMAs.

\subsection{Estimation Strategy}

In the model the independent variables are price, nutritional characteristics, advertising, the natural logarithm of within-group market shares, household income, use of in-store displays as well as DMA dummy variables. Nutritional characteristics used in this model include calories, sodium, protein, and sugar. Nutritional data was sourced from the websites of Hershey and Mars. Table 3 provides us with the nutritional characteristics of the brands. Table 3 also shows how each brand is grouped in each specification. The column labelled Group 1 shows which brands belong to the two nests in specification 1 (Hersheys or Mars). The column labelled Group 2 shows which brands belong to which nest in specification 2 (nuts or no nuts). Table 4 gives us the means of price, market share and within group market share for each brand over 35 months from February 2006 to December 2008. Table 5 provides some descriptive statistics (mean, standard deviation, minimum and maximum) on selected explanatory variables. Within group share 1 represents the within group share for specification 1 while within group share 2 represents the within group share for specification 2 .

As Berry (1994) suggests, price and within group market share are endogenous. Price is correlated with the error term because it is a function of marginal cost. It is also a markup that is an indicator of some change in the market (Nevo, 2001). Within group market shares are endogenous because they might be affected by the brand's market share $s_{j}$ (Kusuda, 2011). Advertising is also endogenous because it has an effect on market shares and firms adjust the amount of advertising they put out based on their market share. Using ordinary least squares (OLS) would lead to misleading results. To control for endogeneity and eliminate any potential biases, I used a set of instrumental variables (IVs) in the regression. Instrumental variables have to be correlated with the explanatory variable and they have to be uncorrelated with the unobservables. Berry (1994) suggests the use of input prices as an instrument for price. I use the per ounce world price of cocoa, a vital ingredient in chocolate manufacturing, as an instrument for price. The data for cocoa prices comes from the International Cocoa Organization. I also use the per ounce price of milk as another instrument for price. Milk price data comes from the website of the University of Wisconsin Department of Agricultural and Applied Economics. Berry (1994) suggests using the characteristics of other firms within the group as an instrument for within group shares. I use the average of within group market share over all other cities during all periods as my instrument for within group shares. Average advertising expenditures over all other cities during all periods serve as an instrument for advertising. The model was estimated in STATA using Two-stage least squares (2SLS). OLS results are also provided.

I use two specifications for this paper. The first uses Hersheys and Mars as the two nests in the nested logit model. This nest is thus based on whichever firm supplies the brand. The second specification divides the brands into those that have nuts (Hersheys with Almonds, Peanut M\&M, etc.) with those that do not have nuts (Hersheys Special Dark, Dove, etc.). I chose this nest because consumers may have strong preferences for buying chocolate with or without nuts. Some people may like the taste or texture of nuts while others may not like it or may have an allergic reaction to it. 
Table 3. Nutritional characteristics (in grams)

\begin{tabular}{|c|c|c|c|c|c|c|}
\hline Brand & Group 1 & Group 2 & Calories & Sodium & Protein & Sugar \\
\hline Hershey's Kisses & Hershey & No nuts & 138.29 & 24.20 & 2.07 & 15.90 \\
\hline Hershey's Milk Chocolate with Almonds & Hershey & Nuts & 145.20 & 17.29 & 2.77 & 13.14 \\
\hline Hershey's Milk Chocolate & Hershey & No nuts & 138.45 & 23.08 & 1.98 & 15.82 \\
\hline Reese's Peanut Butter Cups & Hershey & Nuts & 141.75 & 101.25 & 3.37 & 14.17 \\
\hline Hershey's Special Dark & Hershey & No nuts & 131.38 & 10.37 & 1.38 & 14.52 \\
\hline Hershey's Kissables & Hershey & No nuts & 140.00 & 20.00 & 2.00 & 16.67 \\
\hline M\&M Peanut & Mars & Nuts & 143.68 & 14.37 & 2.87 & 14.37 \\
\hline Milky Way & Mars & No nuts & 126.83 & 46.34 & 0.98 & 17.07 \\
\hline Snickers & Mars & Nuts & 135.23 & 67.61 & 1.93 & 14.49 \\
\hline 3 Musketeers & Mars & No nuts & 122.03 & 51.63 & 0.94 & 18.77 \\
\hline Twix Caramel & Mars & No nuts & 139.79 & 55.92 & 1.12 & 13.42 \\
\hline M\&M Plain & Mars & No nuts & 142.01 & 17.75 & 1.18 & 18.34 \\
\hline Dove & Mars & No nuts & 152.12 & 17.29 & 1.38 & 15.21 \\
\hline
\end{tabular}

Table 4. Mean statistics for price and market share

\begin{tabular}{lcccc}
\hline \multicolumn{1}{c}{ Brand } & Price $(\$ /$ oz. $)$ & Market Share & Within Group Share 1 & Within Group Share 2 \\
\hline Hershey's Kisses & 0.2085 & 0.0227 & 0.3028 & 0.2290 \\
Hershey's Milk Chocolate with Almonds & 0.3738 & 0.0045 & 0.0690 & 0.0757 \\
Hershey's Milk Chocolate & 0.3025 & 0.0118 & 0.1807 & 0.1338 \\
Reese's Peanut Butter Cups & 0.2692 & 0.0227 & 0.3162 & 0.3366 \\
Hershey's Special Dark & 0.3488 & 0.0050 & 0.0790 & 0.0584 \\
Hershey's Kissables & 0.2756 & 0.0042 & 0.0556 & 0.0416 \\
M\&M Peanut & 0.1943 & 0.0225 & 0.2628 & 0.3620 \\
Milky Way & 0.3031 & 0.0060 & 0.0639 & 0.0629 \\
Snickers & 0.2784 & 0.0155 & 0.1668 & 0.2258 \\
3 Musketeers & 0.3360 & 0.0072 & 0.0771 & 0.0761 \\
Twix Caramel & 0.3232 & 0.0044 & 0.0483 & 0.0471 \\
M\&M Plain & 0.2045 & 0.0283 & 0.3196 & 0.2996 \\
Dove & 0.3908 & 0.0053 & 0.0632 & 0.0554 \\
\hline
\end{tabular}

Table 5. Descriptive statistics of select explanatory variables

\begin{tabular}{lcccc}
\hline Variable & Mean & SD & Min & Max \\
\hline Price (\$oz.) & 0.2928 & 0.1499 & 0.0220 & 3.6239 \\
Within Group Share 1 & 0.1548 & 0.1320 & 0.0001 & 0.9101 \\
Within Group Share 2 & 0.1547 & 0.1369 & 0.0001 & 0.9146 \\
Advertising & 1483.881 & 1445.079 & 0 & 7652.612 \\
\hline
\end{tabular}

\section{Results}

Table 6 presents the estimation results and almost all coefficients are significant and have the expected signs. The price coefficient is negative as was expected meaning that an increase in price reduces consumers' utility. The within group share coefficient for specifications 1 and 2 are 0.680 and 0.643 respectively meaning that there is a high level of correlation between consumers' utility within a firm. As I described earlier, this variable is a measure of the degree of correlation between the nests. As the within group share coefficient approached one it shows a higher degree of substitution. The coefficients for the two specifications are both relatively high indicating that the correlation between nests in both specifications is relatively high and that consumers value the products within the nests similarly. Therefore consumers consider Hershey chocolates as a substitute for Mars chocolates. They also consider nutty chocolates as a substitute for smooth chocolates. Table 6 also shows that both advertising and in-store displays have a positive and significant effect on demand. The coefficient for in-store displays is slightly larger than that of advertising in specification 1 while the coefficient for advertising is much larger than that of in-store displays in specification 2. Both in-store displays and advertising thus steepen and expand the demand for chocolate. It is interesting to note that in the OLS regressions, advertising is not 
significant and is negative. However seeing that in-store displays have a higher impact than advertising in specification 2 could lend credence to Hersheys strategy to emphasize in-store displays. As we know in-store displays do tend to promote impulse purchases. The coefficients for all product characteristics except sugar are significant as well. The results show that consumers prefer chocolates with higher contents of calories and sodium and lower content of protein. The coefficient for sugar however is positive in specification 1 and negative in specification 2. The coefficient for household income is positive and significant for both specifications meaning that chocolate demand increases as income goes up.

I use the 2SLS results of specification 2 (nuts or no nuts) to come up with the elasticity table (Table 7). The coefficients for price and within group market shares allow us to estimate the own and cross-price elasticities which are shown in Table 7. I use average price and average within group market share in each group to estimate the elasticities. Cross-price elasticities are higher between brands within the same group as compared to those between brands in different groups. This means that the substitution patterns are stronger within the nest. Therefore if the price of brand $j_{l}$ in nest $g_{l}$ increases, the consumer will prefer to shift his consumption to brand $j_{2}$ in nest $g_{1}$ instead of any other brand $j$ in nest $g_{2}$. The cross-price elasticities are positive signifying that they serve as substitutes instead of complements.

\section{Conclusion}

This paper used a nested logit model to estimate the effect of in-store displays and advertising on the demand for chocolate using scanner data that tracked the purchase of chocolate by thousands of households in sixteen American cities over a span of 35 months. The results show that in-store displays and advertising both help increase the demand for chocolate. In the first specification both advertising and in-store displays have roughly the same impact on sales while in the second specification advertising has a bigger impact compared to in-store displays. It is therefore imperative that advertising is included in demand estimation models for chocolate or other differentiated products so that price impact biases could be avoided.

Table 6. Estimation results

\begin{tabular}{|c|c|c|c|c|}
\hline \multirow[b]{2}{*}{ Variables } & \multicolumn{2}{|c|}{ Specification 1} & \multicolumn{2}{|c|}{ Specification 2} \\
\hline & OLS & 2SLS & OLS & 2SLS \\
\hline \multirow[t]{2}{*}{ Price } & $-0.3764 * *$ & $-3.2324 * *$ & $-0.4288 * *$ & $-3.5908 * *$ \\
\hline & $(0.0591)$ & $(0.6760)$ & $(0.0596)$ & $(0.6814)$ \\
\hline \multirow[t]{2}{*}{ Within group share } & $0.9422 * *$ & $0.6797 * *$ & $0.8957 * *$ & $0.6433^{* *}$ \\
\hline & $(0.0173)$ & $(0.0724)$ & $(0.0168)$ & $(0.0727)$ \\
\hline \multirow[t]{2}{*}{ Advertising } & -0.0845 & $0.3684 *$ & -0.0039 & $0.6413^{* *}$ \\
\hline & $(0.0843)$ & $(0.1453)$ & $(0.0085)$ & $(0.1605)$ \\
\hline \multirow[t]{2}{*}{ In-store Display } & $0.3694 * *$ & $0.3979 * *$ & $0.3797 * *$ & $0.3934 * *$ \\
\hline & $(0.0270)$ & $(0.0388)$ & $(0.0273)$ & $(0.0413)$ \\
\hline \multirow[t]{2}{*}{ Calories } & $0.0230 * *$ & $0.0325^{* *}$ & $0.0142 * *$ & $0.0252 * *$ \\
\hline & $(0.0024)$ & $(0.0044)$ & $(0.0025)$ & $(0.0053)$ \\
\hline \multirow[t]{2}{*}{ Sodium } & $0.0066^{* *}$ & $0.0062 * *$ & 0.0009 & $0.0019 *$ \\
\hline & $(0.0006)$ & $(0.0008)$ & $(0.0006)$ & $(0.0010)$ \\
\hline \multirow[t]{2}{*}{ Protein } & $-0.4474 * *$ & $-0.3273 * *$ & $-0.2333^{* *}$ & $-0.1700 * *$ \\
\hline & $(0.0306)$ & $(0.0508)$ & $(0.0299)$ & $(0.0440)$ \\
\hline \multirow[t]{2}{*}{ Sugar } & $-0.0317 * *$ & -0.0036 & $0.0235^{*}$ & 0.0284 \\
\hline & $(0.0103)$ & $(0.0179)$ & $(0.0101)$ & $(0.0166)$ \\
\hline \multirow[t]{2}{*}{ Household Income } & $0.1400 *$ & $0.2097 * *$ & $0.1570 * *$ & $0.2184 * *$ \\
\hline & $(0.0591)$ & $(0.0796)$ & $(0.0597)$ & $(0.0839)$ \\
\hline $\mathrm{R}$-squared & 0.6843 & 0.9580 & 0.6775 & 0.9531 \\
\hline \multirow[t]{2}{*}{ Constant } & $-4.8729 * *$ & $-6.3996^{* *}$ & $-4.7404 * *$ & $-5.9621 * *$ \\
\hline & $(0.4225)$ & $(0.8110)$ & $(0.4296)$ & $(0.8985)$ \\
\hline \multirow[t]{2}{*}{ Hansen J statistic } & & 3.387 & & 3.641 \\
\hline & & $(\mathrm{p}=0.0657)$ & & $(\mathrm{p}=0.0564)$ \\
\hline DMA dummies & Yes & Yes & Yes & Yes \\
\hline
\end{tabular}


Table 7. Own and cross-price elasticities

\begin{tabular}{|c|c|c|c|c|c|c|c|c|c|c|c|c|c|}
\hline & $\begin{array}{c}\mathrm{H} . \\
\text { Kisses }\end{array}$ & $\begin{array}{l}\text { H. Milk Choco } \\
\text { w/ Almonds }\end{array}$ & $\begin{array}{c}\text { H. Milk } \\
\text { Chocolate }\end{array}$ & $\begin{array}{l}\text { Reese's } \\
\text { PB Cups }\end{array}$ & $\begin{array}{l}\text { H. Special } \\
\text { Dark }\end{array}$ & $\begin{array}{c}\text { H. } \\
\text { Kissables }\end{array}$ & $\begin{array}{l}\text { M\&M } \\
\text { Peanut }\end{array}$ & $\begin{array}{c}\text { Milky } \\
\text { Way }\end{array}$ & Snickers & $\begin{array}{c}3 \\
\text { Musk. }\end{array}$ & $\begin{array}{c}\text { Twix } \\
\text { Caramel }\end{array}$ & $\begin{array}{c}\text { M\&M } \\
\text { Plain }\end{array}$ & Dove \\
\hline H. Kisses & -1.7727 & 0.5848 & 0.4733 & 0.4212 & 0.5457 & 0.4312 & 0.0158 & 0.0247 & 0.0227 & 0.0274 & 0.0263 & 0.0167 & 0.0319 \\
\hline \multicolumn{14}{|l|}{ H. Milk Choco w/ } \\
\hline Almonds & 0.1056 & -3.5737 & 0.1532 & 0.1363 & 0.1766 & 0.1396 & 0.0031 & 0.0049 & 0.0045 & 0.0054 & 0.0052 & 0.0033 & 0.0063 \\
\hline H. Milk Chocolate & 0.1895 & 0.3397 & -2.7703 & 0.2447 & 0.3170 & 0.2505 & 0.0082 & 0.0128 & 0.0118 & 0.0142 & 0.0137 & 0.0087 & 0.0166 \\
\hline Reese's PB Cups & 0.4715 & 0.8453 & 0.6840 & -2.1012 & 0.7887 & 0.6232 & 0.0158 & 0.0247 & 0.0227 & 0.0274 & 0.0263 & 0.0167 & 0.0319 \\
\hline M\&M Peanut & 0.2710 & 0.4859 & 0.3932 & 0.3499 & 0.4534 & 0.3582 & -1.6751 & 0.4382 & 0.4024 & 0.4857 & 0.4672 & 0.2956 & 0.5649 \\
\hline Milky Way & 0.0471 & 0.0844 & 0.0683 & 0.0608 & 0.0788 & 0.0622 & 0.0514 & -2.9710 & 0.0737 & 0.0889 & 0.0856 & 0.0541 & 0.1035 \\
\hline Snickers & 0.1691 & 0.3031 & 0.2453 & 0.2183 & 0.2828 & 0.2235 & 0.1770 & 0.2762 & -2.5489 & 0.3062 & 0.2945 & 0.1863 & 0.3561 \\
\hline 3 Musk. & 0.0570 & 0.1021 & 0.0827 & 0.0736 & 0.0953 & 0.0753 & 0.0622 & 0.0970 & 0.0891 & -3.2749 & 0.1034 & 0.0654 & 0.1250 \\
\hline Twix Caramel & 0.0353 & 0.0632 & 0.0512 & 0.0455 & 0.0590 & 0.0466 & 0.0384 & 0.0599 & 0.0550 & 0.0664 & -3.1897 & 0.0404 & 0.0772 \\
\hline
\end{tabular}

\section{References}

Ackerberg, D. A. (2001). Empirically distinguishing informative and prestige effects of advertising. Rand Journal of Economics, 32(2), 316-333.

Allenby, G. M., \& Ginter, J. L. (1995). The effects of in-store displays and feature advertising on consideration sets. International Journal of Research in Marketing, 12(1), 67-80. http://dx.doi.org/10.1016/0167-8116(95)00006-N

Allenby, G. M., \& Lenk, P. J. (1995). Reassessing brand loyalty, price sensitivity, and merchandising effects on consumer brand choice. Journal of Business \& Economic Statistics, 13(3), 281-289. http://dx.doi.org/10.2307/1392188

Bagwell, K. (2005). The economic analysis of advertising. Columbia University Department of Economics Discussion Paper No. 0506-01.

Bemmaor, A. C., \& Mouchoux, D. (1991). Measuring the short-term effect of in-store promotion and retail advertising on brand sales: A factorial experiment. Journal of Marketing Research, 28(2), 202-214. http://dx.doi.org/10.2307/3172808

Berry, S. T. (1994). Estimating discrete-choice models of product differentiation. The Rand Journal of Economics, 25(2), 242-262.

Berry, S. T., Levinsohn, J., \& Pakes, A. (1995). Automobile prices in market equilibrium. Econometrica, 63(4), 841-890. http://dx.doi.org/10.2307/2171802

Blattberg, R. C., Briesch, R., \& Fox, E. J. (1995). How promotions work. Marketing Science, 14(3), G122-G132.

Bruno, H. A., \& Vilcassim, N. J. (2008). Structural demand estimation with varying product availability. Marketing Science, 27(6), 1126-1131. http://dx.doi.org/10.1287/mksc.1080.0366

Carlton, D., \& Perloff, J. (2005). Modern industrial economics (4th ed.). Boston: Pearson.

Chintagunta, P. K., Jain, D. C., \& Vilcassim, N. J. (1991). Investigating heterogeneity in brand preferences in logit models for panel data. Journal of Marketing Research, 28(4), 417-428. http://dx.doi.org/10.2307/3172782

Cotterill, R. W., \& Haller, L. E. (1997). An econometric analysis of the demand for RTE cereal: Product market definition and unilateral market power effects. Food Marketing Policy Center Research Report No. 35, University of Connecticut, Storrs, CT.

Eagle, B., \& Ambler, T. (2002). The influence of advertising on the demand for chocolate confectionery. International Journal of Advertising, 21(4), 437-454. http://dx.doi.org/10.1080/02650487.2002.11104945

Erdem, T., \& Keane, M. (1996). Decision-making under uncertainty: Capturing dynamic brand choice processes in turbulent consumer goods markets. Marketing Science, 15(1), 1-20. 
Fitzgerald, R. (2005). Products, firms and consumption: Cadbury and the development of marketing, 1900-1939. Business History, 47(4), 511-531. http://dx.doi.org/10.1080/00076790500132977

Goldberg, P. K. (1995). Product differentiation and oligopoly in international markets: The case of the U.S. automobile industry. Econometrica, 63(4), 891-951. http://dx.doi.org/10.2307/2171803

Kumar, V., \& Leone, R. P. (1988). Measuring the effect of retail store promotions on brand and store substitution. Journal of Marketing Research, 25(2), 178-185. http://dx.doi.org/10.2307/3172649

Kusuda, Y. (2011). Nested logit demand estimation in Japanese beer-like beverage markets. Paper presented at the Tenth International Conference of the Japan Economic Policy Association.

McFadden, D. (1974). Conditional logit analysis of qualitative choice behavior. In P. Zarembka (Ed.), Frontiers in econometrics (pp. 105-142). New York: Academic Press.

MarketLine. (2013, January). Industry profile: Chocolate confectionery in the United States. Retrieved from EBSCOhost database.

Michman, R. D., \& Mazze, E. M. (1998). The food industry wars: Marketing triumphs and blunders. Westport, CT: Quorum Books.

National Confectioners Association. (n.d.). NCA sweet insights, consumer insights: Chocolate. Retrieved from http://www.candyusa.com/files/SweetInsights/NCA\%20Sweet\%20Insights\%20-\%20Chocolate\%20Consum er\%20-\%20Final.pdf

Nevo, A. (2001). Measuring market power in the ready-to-eat cereal industry. Econometrica, 69(2), 307-342. http://dx.doi.org/10.1111/1468-0262.00194

Porter, M. E. (1974). Consumer behavior, retailer power and market performance in consumer goods industries. The Review of Economics and Statistics, 56(4), 419-436. http://dx.doi.org/10.2307/1924458

Rossfeld, R. (2008). Suchard and the emergence of traveling salesmen in Switzerland, 1860-1920. Business History Review, 82(4), 735-759.

Scott, P., \& Walker, J. (2010). Advertising, promotion and the competitive advantage of interwar British

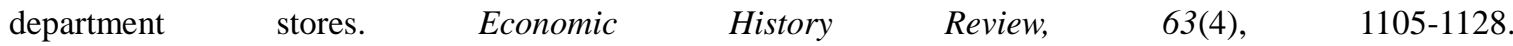
http://dx.doi.org/10.1111/j.1468-0289.2010.00535.x

Shaffer, G., \& Zettelmeyer, F. (2009). Comparative advertising and in-store displays. Marketing Science, 28(6), 1144-1156. http://dx.doi.org/10.1287/mksc.1090.0521

Shum, M. (2004). Does advertising overcome brand loyalty? Evidence from the breakfast cereals markets.

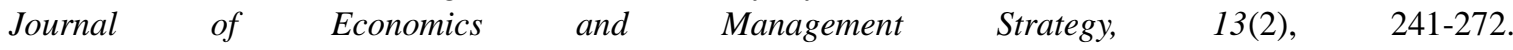
http://dx.doi.org/10.1111/j.1530-9134.2004.00010.x

Snell, A., \& Tonks, I. (1988). The sweet taste of information: A study of the demand for new brands in the UK confectionery industry. Applied Economics, 20(8), 1041-1055.

Volle, P. (2001). The short-term effect of store-level promotions on store choice, and the moderating role of individual variables. Journal of Business Research, 53(2), 63-73. http://dx.doi.org/10.1016/S0148-2963(99)00074-0

Walters, R. G., \& MacKenzie, S. B. (1988). A structural equations analysis of the impact of price promotions on store performance. Journal of Marketing Research, 25(1), 51-63. http://dx.doi.org/10.2307/3172924

Woodside, A. G., \& Waddle, G. L. (1975). Sales effects of in-store advertising. Journal of Advertising Research, 15(3), 29-33.

Zhang, J. (2006). An integrated choice model incorporating alternative mechanisms for consumers' reactions to in-store display and feature advertising. Marketing Science, 25(3), 278-290. http://dx.doi.org/10.1287/mksc.1050.0170

\section{Copyrights}

Copyright for this article is retained by the author(s), with first publication rights granted to the journal.

This is an open-access article distributed under the terms and conditions of the Creative Commons Attribution license (http://creativecommons.org/licenses/by/3.0/). 